Meta

Journal des traducteurs

Translators' Journal

\title{
Translation of Poems
}

\section{Vittorio Felaco}

Volume 27, numéro 3, septembre 1982

URI : https://id.erudit.org/iderudit/002739ar

DOI : https://doi.org/10.7202/002739ar

Aller au sommaire du numéro

Éditeur(s)

Les Presses de l'Université de Montréal

ISSN

0026-0452 (imprimé)

1492-1421 (numérique)

Découvrir la revue

Citer cette note

Felaco, V. (1982). Translation of Poems. Meta, 27(3), 351-351.

https://doi.org/10.7202/002739ar

Ce document est protégé par la loi sur le droit d'auteur. L’utilisation des services d'Érudit (y compris la reproduction) est assujettie à sa politique d'utilisation que vous pouvez consulter en ligne.

https://apropos.erudit.org/fr/usagers/politique-dutilisation/
Cet article est diffusé et préservé par Érudit.

Érudit est un consortium interuniversitaire sans but lucratif composé de l'Université de Montréal, l'Université Laval et l'Université du Québec à Montréal. Il a pour mission la promotion et la valorisation de la recherche. https://www.erudit.org/fr/ 


\section{TRANSLATION OF POEMS}

\section{«La bambina che va sotto gli alberi »}

La bambina che va sotto gli alberi non ha che il peso della sua treccia, un fil di canto in gola.

Canta sola

5 e salta per la strada; ché non sa che mai bene piú grande non avrà di quel po' d'oro vivo per le spalle, di quella gioia in gola. A noi che nò abbiamo e non l'acceso fiocco e non la molta speranza che fa grosso a quella il cuore, se non è troppo chiedere, sia tolta prima la vita di quel solo bene.

\section{Camillo Sbarbaro : Versi a Dina}

The girl that runs under the trees has no burden but that of her tresses and a tiny song in her voice.

She sings alone

and jumps along the way; for she does not know that greater joy she'll never have than that bit of lively gold on her back and that joy in her throat.

We who hold no other happiness except of words, and no bright colored bow upon our nape nor the vast

hope that fills her heart to overflowing, if it's not too much to ask, take first our life than that lonely joy.

\section{Donna genovese}

Tu mi portasti un po' d'alga marina Nei tuoi capelli, ed un odor di vento, Che è corso di lontano e giunge grave D'ardore, era nel tuo corpo bronzino: - Oh la divina

Semplicità delle tue forme snelle -

Non amore non spasimo, un fantasma,

Un'ombra della necessita che vaga

Serena e ineluttabile per l'anima

$\mathrm{E}$ la discioglie in gioia, in incanto serena

Perché per l'infinito lo scirocco

Se la possa portare.

Come è piccolo il mondo e leggero nelle tue you brought me a bit of seaweed in your hair amid the scent of wind that came from afar laden with warmth, it was your bronzed body: - Oh the divine

simplicity of your slender figure.

Not love not even agony, a phantom, a shadow of the necessity that wanders serene and inevitable in the soul and dissolves it in joy, in enchantment serene so scirocco may carry it into infinity.

How small the world and light upon your hands 